\title{
HUMAN CAPITAL QUALITY AND DEVELOPMENT: AN EMPLOYERS' AND EMPLOYEES' COMPARATIVE INSIGHT
}

\author{
Olimpia Neagu \\ Vasile Lazar \\ Mircea Teodoru \\ Simona Macarie \\ "Vasile Goldis" Western University of Arad
}

(Received May 2016; Accepted July 2016)

\begin{abstract}
The aim of the paper is to compare the employers' and employees' insights on human capital quality defining and human capital development at organisational level, based on a survey carried out in the county of Satu Mare, Romania. Our findings show that as human capital buyers, employers understand by human capital quality professional background and skills, professional behaviour and efficiency and productivity for the organisation. As human capital sellers, for employees human capital quality means health and the ability to learn and to be suitable to the job requirements. Regarding the opportunities to develop the organisational human capital, the views of employers and employees are very different when the level of discussion is international (macro-level). Employees consider that the international environment has a greater impact on human capital development in their organisation as the employers.
\end{abstract}

Key words: human capital quality, human capital development, labour force

JEL CODES: J24, J21, M21

\section{Introduction}

Defining, measuring and optimizing human capital are critical for companies to compete in the current turbulent economy and companies that best manage their human capital will be the most successful. Organizations recognize the importance of human capital management for their market success.

There is strong evidence to show that the infusion of human capital enhancement in organisations promotes innovativeness and greater company performance. Studies also clearly substantiate the fact that financial performance is positively impacted through the consideration of human capital (Marimuthu et al., 2009). Employers and employees can be placed on opposite positions when they evaluate the content and the opportunities to enhance organisational human capital in order to lead business performance. This divergence of views is generated by the different positions on which are posed the two actors: human capital buyers and sellers. Employers are interested to attract, buy and retain a high quality human capital and with a low investment in their further education and training. Employees are

62 Studia Universitatis "Vasile Goldis" Arad. Economics Series Vol 26 Issue 3/2016 
Neagu O., Lazăr V., Mircea T., Macarie S. (2016)

Human capital quality and development: an employers' and employees' comparative insight

interested to sell their human capital at a higher price (salary) and to have opportunities to develop their knowledge and human capabilities. A matching between the two sides or measuring the gap between them has relevance for effectiveness of business plans in generating market performance and sustainable competitive advantages.

The aim of the paper is to compare the employers' and employees' insights on human capital quality defining and human capital development at organisational level, based on a survey carried out in the county of Satu Mare, Romania.

The paper is organized as follows: a short literature review on human capital concept is followed by conceptual remarks, methodology and data section, then main findings are described and conclusions are exposed in the last section.

\section{Literature review on organisational human capital concept}

Behrman and Taubman (1982) defined human capital as the stock of economically productive human capabilities. Human capital can be increased through education expenditure, on-the job training and investment in health and nutrition.

The concept of human capital has been defined in relation with the improving of the company assets and employees in order to increase productivity as well as sustain competitive advantage (Schultz, 1993).

The World Bank (2006) defined human capital as the sum of knowledge, skills, and know-how possessed by the population, contributing to economic production.

Human capital was defined by OECD as "the knowledge, skills, competences and other attributes embodied in individuals that are relevant to economic activity" (OECD, 1998). A later report, however, defined human capital as "the knowledge, skills, competencies and attributes embodied in individuals that facilitate the creation of personal, social and economic well-being" (OECD, 2001).

The OECD definition is all-embracing. It incorporates various skills and competencies that are acquired through learning and experience but may also include innate abilities. Some aspects of motivation and behaviour, as well as the physical, emotional and mental health of individuals are also regarded as human capital in this broader definition (OECD, 2011). The components of human capital proposed by the OECD reflect its multi-faceted nature. For instance, they include both general and work-specific skills, both tacit and explicit ones. They cover not only the cognitive skills that were conventionally recognised by research in this field but also non-cognitive skills such as intra- and inter-personal skills that have assumed an increasingly important role in modern societies.

In general meaning, as knowledge and skills, company-specific human capital makes workers more productive and effective in attaining the company business goals. Human capital refers to process related, training, education and other 
Neagu O., Lazăr V., Mircea T., Macarie S. (2016)

Human capital quality and development: an employers' and employees' comparative insight

professional initiatives in order to increase the levels of knowledge, skills, abilities, values and social assets of an employee which will lead to the employee's satisfaction and performance and company competitive advantage.

Rastogi (2002) stated that human capital is an important input for organizations especially for employees' continuous improvement mainly on knowledge, skills, and abilities.

Becker (1993) distinguished between company-specific human capitals and general-purpose human capital. Examples of company-specific human capital include expertise obtained through education and training in management systems, financial-accounting procedures or other expertise methods that are specific to a particular company. General-purpose human capital is the generic knowledge and skills gained through human resources' development. Becker considers education and training to be the most important investment in human capital.

A company's human capital asset is the collective sum of the attributes, life experience, knowledge, inventiveness, energy and enthusiasm that its people choose to invest in their work (Weatherly et al., 2003).

Differently from economic capital, all types of knowledge, skills, competencies and attributes are invisible. However, both human and economic capital accumulation through investments are decreasing through use and obsolescence, although in different ways. For example, while economic capital will wear out through use, human capital typically grows through use and experience, while it depreciates due to lack of use, obsolescence of knowledge, population ageing and many other factors (Boarini et al., 2012).

Based on the classical human capital theory, Wang et al. (2012) proposed a connotation of human capital quality which is a combination of knowledge, techniques, capabilities and health that are embedded in labour and with economic values. They developed a theoretical model of human capital quality, with a threedimensional structure, consisting of health awareness, education effect and family background.

Human capital development has been described as a key economic driver (Benhabib\&Spiegel, 1994; Schultz, 1961). Other authors examined the relationship between human capital and value creation and employee reward. For example, Massingham and Tam (2015) conducted a study in public Australian companies and found that employees' capabilities and satisfaction had a positive relationship with the importance of work activity and the employees' capabilities are related to the pay. The findings of other studies conducted in Portuguese innovative SMEs indicate that human capital does have a significant and positive relationship with product innovation performance (Costa et al., 2015). 
Neagu O., Lazăr V., Mircea T., Macarie S. (2016)

Human capital quality and development: an employers' and employees' comparative insight

In their studies carried out in 635 Romanian companies, Lafuente and Rabetino (2011) have found that human capital (meaning education, previous work experience, the presence of entrepreneurial teams and the proportion of family members working in the business) matters for accounting for the small company' employment growth.

The organisational human capital quality can be seen as organisational intelligence in relationship with the learning process at organisational level. A pilot research conducted in Romanian companies by Lefter et al. (2008) show that organisational intelligence is an unfamiliar concept to them and there is a lack of systemic thinking in order to make the linkage between organisational intelligence, learning and development.

The organisational intellectual capital, comprising human capital as a component, was explored in several studies. A new perspective of organisational intellectual capital is introduced by the work of Professor Bratianu (Bratianu, 2007 and 2008; Bratianu et al., 2011) which analysed the organisational intellectual capital as an integral result of a generative process, based on some core integrators (technology, management and leadership, mission, vision and organisational culture). At individual level, human capital can be structured in three independent entities: knowledge, intelligence and values. Accordingly, the intellectual capital comprises organisational knowledge, organisational intelligence and organisational culture.

\section{Conceptual remarks, methodology and data}

Based on the above considerations, and for the purpose of this study, we accept that human capital quality means a combination of knowledge, capabilities and noncognitive traits, embodied in humans and with economic value. Human capital quality means knowledge and skills, experience, professional behaviour; capacity to be efficient and productive for the firm, personal traits, health status, geographical mobility and learning capacity.

According to this concept we put forward a three-dimensional structure of human capital quality which is constructed by: 1.cognitive aspects (knowledge, skills, experience, and professional behaviour); 2 capacities (to be efficient and productive, to learn); and 3.non-cognitive aspects (personal traits, health status, geographical mobility) (Figure 1).

Further, we suggest as means for human capital development at organisational level the following possibilities related to the two levels of its business environment: micro and macro-level. At micro-level, organisation is able to evaluate its own human capital and it has to continually develop its human capital, through education and training, through hiring and replacement. At macro-level, a higher international dynamics of labour force and an improved knowledge on 
Neagu O., Lazăr V., Mircea T., Macarie S. (2016)

Human capital quality and development: an employers' and employees' comparative insight

international labour market and educational system could be mentioned as possibilities for human capital development.

Figure 1 Structure of human capital quality concept

\begin{tabular}{|l|}
\hline \multicolumn{2}{|c|}{ HUMAN CAPITAL QUALITY } \\
\begin{tabular}{|l|l|l|}
\hline Cognitive aspects & $\begin{array}{l}\text { Capacities: } \\
\text {-knowledge, }\end{array}$ & -to be efficient and \\
productive, & Non-cognitive aspects \\
-skills, & -personal traits, \\
-experience, & -to learn & \\
-professional behaviour & -geographical mobility \\
\hline
\end{tabular}
\end{tabular}

Source: own authors' view

In our survey, the respondents were asked to select one or more of the following statements:

The human capital quality of a company consists of the following characteristics of employees:

1. professional background

2. professional and practical abilities

3. professional behaviour, moral qualities

4. efficiency and productivity for company

5. personality traits

6. health status

7. geographical mobility

8. learning capacity

The frequencies of answers were cumulated and their ranking was made.

The respondents were also asked to assess the truthfulness of the following statements in the company where they work, on a scale from 1 (not at all) to 5 (very truthful):

1. organisation is able to evaluate its own human capital

2. it is important to continually develop human capital

3. human capital development must be made through education and training within companies

4. human capital development consists of hiring and replacement

5. human capital development could be facilitated through a higher international dynamic of labour force

6. human capital development could be facilitated through an improved knowledge on labour market and educational system at international level 
Neagu O., Lazăr V., Mircea T., Macarie S. (2016)

Human capital quality and development: an employers' and employees' comparative insight

The mean scores for each statement were calculated by the Likert scale and made their ranking.

The respondents were employers and employees. The first part of the study, regarding the employers, was conducted in 2012 during the implementation of a cross border Hungarian-Romanian project financed by European Union through 2007-2013 Hungarian Romanian Cross Border Programme (HURO/0901/264/2.2.2.) and the second part, regarding the employees, in 20132014, as a follow-up of the mentioned project.

In the sample were included 65 Romanian business companies located in the county of Satu Mare from representatives branches: agriculture, manufactures, construction, trade and services. The 65 surveyed companies are active in the following activity sectors (NACE 2): Agriculture, forestry and fishery $(4,5 \%)$, Manufacturing (8\%), Electricity (4\%), Constructions (4\%), Trade and car repair $(3,5 \%)$, Transport and storage $(5,5 \%)$, Hotels and hospitality services $(3,5 \%)$, Informational and communicational technologies (ICT) (4\%), Financial activities/insurances (3,5\%) scientific/technical activities(3,5\%), Public administration, defence and social insurances (12\%), Education (12\%), Health and social assistance $(6,5 \%)$, Arts and leisure (4\%), Mining and quarrying (1\%), Production/services for own consumption $(8,5 \%)$, Other services $(12 \%) .32 \%$ of the surveyed companies were small enterprises (5-9 employees) and $68 \%$ were small and medium.

The survey aimed at exploring the business employers and their employees' views regarding several aspects related to their company's human capital. For the purpose of the present survey we extracted two aspects: "what they understand by human capital quality" and "how human capital can be developed at company level".

\section{Main findings}

As we can notice from the Table 1, the highest gap between employers and employees' view on human capital quality is recorded for professional background and professional practical skills, meaning a very divergent opinion on these aspects of human capital quality. According to employers' opinion, professional background and professional and practical skills are very important for the quality of human capital.

At the opposite side, employees are saying that these are not so important as learning capacity and other personality traits. This high divergence could be generated by the opposite positions of employers, as human capital buyers, and of employees as human capital sellers. The human capital buyers (employers) are interested, essentially, to purchase human capital of a high quality based on 
Neagu O., Lazăr V., Mircea T., Macarie S. (2016)

Human capital quality and development: an employers' and employees' comparative insight

professional background and professional practical skills (acquired before to be hired).

Table 1. Comparison of employers and employees' views on human capital quality concept

\begin{tabular}{|l|c|c|c|}
\hline Human capital quality means: & $\begin{array}{c}\text { Employers } \\
\text { ranking }\end{array}$ & $\begin{array}{c}\text { Employees } \\
\text { ranking }\end{array}$ & Gap \\
\hline 1. professional background & 1 & 7 & 6 \\
\hline 2.professional and practical skills & 2 & 8 & 6 \\
\hline 3. professional behaviour, moral qualities & 3 & 5 & 2 \\
\hline 4. efficiency and productivity for organisation & 4 & 4 & 0 \\
\hline 5.personality traits & 7 & 2 & 5 \\
\hline 6. health status & 5 & 3 & 2 \\
\hline 7.geographical mobility & 8 & 6 & 2 \\
\hline 8.learning capacity & 6 & 1 & 5 \\
\hline Source:
\end{tabular}

Source: data collected and processed by authors

The human capital sellers (employees) rely on their capacity to learn and their health status to be productive at a new job.

For a single aspect of human capital quality, efficiency and productivity for company, the views of employers and employees are the same.

A same gap of 2 is registered for professional behaviour, health status, and geographical mobility. Professional behaviour is more valued by the employers and personality traits, health status and geographical mobility are more valuable for employees.

Employers have a very low interest in learning capacity, health status, personality traits and geographical mobility when they are thinking to the quality of the human capital they work with.

Employees are aware that, being hired, they have to learn within the new company, so their professional practical skills and professional background previously acquired are important but no so important as their capacity to adapt to the new working and learning on the job conditions.

Regarding the possibilities to develop the company's human capital, we can see in Table 2 and Figure 2 that the difference between the ranking of the employers and employees' mean scores of their views is very little, the opinions are mainly convergent. Only in 2 cases, there is a difference of 1.

The highest gap between the means scores of employers and employees' view is regarding the sentence "human capital development could be facilitated through a higher international dynamic of labour force", followed by "human capital development could be facilitated through an improved knowledge on labour market 
Neagu O., Lazăr V., Mircea T., Macarie S. (2016)

Human capital quality and development: an employers' and employees' comparative insight

and educational system at international level". Employees value more these opportunities as employers. The reason could consist of a different vision on the impact of such opportunities on the human capital accumulation within the organisation. Employers are aware of their real possibilities to enhance the company's human capital, while employees are a little overstating the influence of the international context on the organisational human capital.

Table 2. Comparison of employers and employees' views on human capital development

\begin{tabular}{|l|c|c|c|c|c|}
\hline \multirow{2}{*}{ Human capital development } & \multicolumn{2}{|c|}{ Employers } & \multicolumn{2}{c|}{ Employees } & $\begin{array}{c}\text { Mean } \\
\text { Scores Gap }\end{array}$ \\
\cline { 2 - 6 } & $\begin{array}{l}\text { Mean } \\
\text { scores }\end{array}$ & Ranking & $\begin{array}{c}\text { Mean } \\
\text { scores }\end{array}$ & Ranking & \\
\hline $\begin{array}{l}\text { 1.organisation is able to evaluate its } \\
\text { own human capital }\end{array}$ & 4,4 & 2 & 3,80 & 2 & 0,6 \\
\hline $\begin{array}{l}\text { 2.it is important to continually develop } \\
\text { human capital }\end{array}$ & 4,44 & 1 & 3,94 & 1 & 0,5 \\
\hline $\begin{array}{l}\text { 3. human capital development must be } \\
\text { made through education and training } \\
\text { within companies }\end{array}$ & 4,14 & 3 & 3,68 & 3 & 0,46 \\
\hline $\begin{array}{l}\text { 4. human capital development consists } \\
\text { of labour force hiring and replacement }\end{array}$ & 2,71 & 4 & 2,68 & 5 & 0,03 \\
\hline $\begin{array}{l}\text { 5. human capital development could be } \\
\text { facilitated through a higher } \\
\text { international dynamic of labour force }\end{array}$ & 2,33 & 6 & 3,12 & 6 & 0,79 \\
\hline $\begin{array}{l}\text { 6.human capital development could be } \\
\text { facilitated through an improved } \\
\text { knowledge on labour market and } \\
\text { educational system at international level }\end{array}$ & 2,57 & 5 & 3,26 & 4 & 0,69 \\
\hline Mean & 3,43 & & 3,41 & & \\
\hline
\end{tabular}

Source: data collected and processed by authors

The most convergent view is related to "human capital development consists of labour force hiring and replacement", on which the gap is the lowest, of 0.03.

For employers, the best possibility to develop the employees' human capital is through education and training within the company. In their opinion, "organisation is able to evaluate its own human capital", and "it is important to continually develop human capital". Employees assign a lower importance to these options. Employees assign a higher importance than employers when they presume that "human capital development could be facilitated through a higher international dynamic of labour force" and "human capital development could be facilitated through an improved knowledge on labour market and educational system at international level". 


\section{EMPLOYEES}

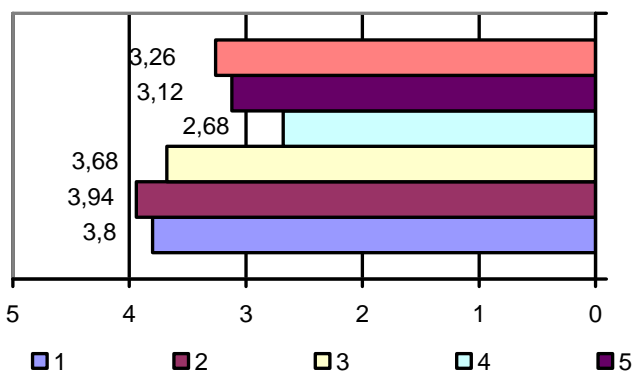

EMPLOYERS

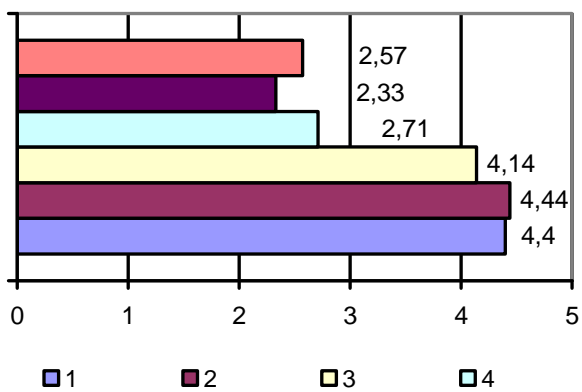

Figure 2. Mean scores of employers and employees' view regarding the company's human capital development

Source: data collected and processed by authors

\section{Discussion}

Employers posed on the first places "the professional knowledge, skills and professional behaviour and efficiency and effectiveness for organisation" as components of the human quality concept. They identified the most cited components of human capital quality concept present in the human capital literature. Employees nominated firstly the components related to human capabilities, personality and health status, which are less referred to in the human capital literature. As importance level, the views are matching for "efficiency and effectiveness for organisation", highlighting a unified vision on which human capital is viewed in relation with improving productivity and efficiency.

The hidden agenda of employers in planning human capital development in their organisations is to achieve a competitive advantage with more educated workers having updated skills at minimized costs of such investment.

\section{Conclusions}

The paper intended to show that employers and employees could have different views when they relate the content of organisational human capital and possibilities to enhance it, in order to increase the business performance.

A first conclusion is that employers and employees cannot have identical views on human capital quality of their organisation. They are on opposite sides. As human capital buyers, employers are interested to purchase a high quality human capital, with professional background and skills, professional behaviour and efficient and 
Neagu O., Lazăr V., Mircea T., Macarie S. (2016)

Human capital quality and development: an employers' and employees' comparative insight

productive for the organisation. Therefore, in their opinion, the human capital quality means professional background and professional practical skills (acquired before to be hired). Their views are partially in line with studies related to human capital quality consisting in knowledge. Bratianu (2007, 2008 and 2011) and Wang et al. (2012) have nominated other components of human capital quality such as: intelligence, values, techniques, capabilities and health.

We found also that, as human capital sellers, employees understand by a qualitative human capital to be able to learn, to be healthy, personality traits, geographical mobility and to be suitable to the job requirements. A reason of this opinion could be their desire to maintain their jobs in the companies where they work in a county marked by the job crisis. Their opinion is close to that of Wang et al. (2012), Becker (1993) and Schultz (1961) for whom human capital means a combination of education, health awareness, mobility and family background.

A second conclusion, as regards the opportunities to develop the organisational human capital, the views are mainly similar. Employers and employees have almost the same insight regarding the statement: "human capital development consists of labour force hiring and replacement". Their views are very different when the level of discussion is international (macro-level). Employees consider that the international environment has a greater impact on human capital development in their organisation as the employers. A possible explanation of this difference could be found in the high mobility of labour force in the surveyed county, where almost $30 \%$ of the active population or in every third family one member is working abroad. For employers, the best possibility to develop the employees' human capital is "through education and training within the company" and they value more than their employees the following statements: "organisation is able to evaluate its own human capital", and "it is important to continually develop human capital".

Our findings have a more practical importance than a theoretical one, by offering to the employers from the surveyed area a valuable feedback from their employees regarding the meaning of human capital quality and development in their companies. For a successful strategic planning of human capital development a convergent vision from both sides, employers and employees, is important.

From the theoretical point of view, our study points out that the concept of human capital quality can be constructed by: 1.cognitive aspects (knowledge, skills, experience, and professional behaviour); 2 capacities (to be efficient and productive, to learn); and 3.non-cognitive aspects (personal traits, health status, geographical mobility) and this structure is differently perceived by employers and employees. We also proposed some possibilities to enhance the human capital development in the Romanian companies. 
Neagu O., Lazăr V., Mircea T., Macarie S. (2016)

Human capital quality and development: an employers' and employees' comparative insight

We consider being necessary to extend our research to other counties and regions of Romania in order to verify the perception of the proposed concept of human capital quality and possibilities to develop the organisational human capital. There are some studies regarding the effect of education on economic growth in Romania (Neagu, 2012, Pribac et al., 2016), but at organisational level, the link between labour force quality and economic performance is less studied.

Our study has some limits. One of them is related to finding out why "it is important to continually develop human capital" and another one is related to the presence of a strategic thinking in the employers' vision on organisational development in relation with the human capital development process through organisational learning and intelligence. In order to clarify these aspects a further research in the same sample is required.

\section{References}

1. Becker G.S. (1993), Human Capital: A Theoretical and Empirical Analysis with Special Reference to Education. (3rd ed.). Chicago: University of Chicago Press.

2. Behrman J.R., Taubman P.J. (1982), Human Capital in: Encyclopedia of Economics, ed. Douglas Greenwald, 474-76. New York: McGraw-Hill Book Company.

3. Benhabib J., Spiegel M. (1994), The role of human capital in economic development: evidence from aggregate cross-country data. Journal of Monetary Economics, 34, pp.143179.

4. Boarini R., Mira d'Ercole M., Liu G. (2012), Approaches to Measuring the Stock of Human Capital: A Review of Country Practices. OECD Statistics Working Papers, 2012/04, OECD Publishing.

5. Bratianu C. (2007), An integrative perspective on the organizational intellectual capital. Review of Management and Economical Engineering, Vol.6 No.5, pp.107-113.

6. Bratianu C. (2008), A dynamic structure of the organizational intellectual capital in: Naaranoja M. (ed.) Knowledge management in organizations, pp.233-243, Vaasa:Vaasan Yliopisto.

7. Bratianu C., Jianu I., Vasilache S. (2011), Integrators for organizational intellectual capital. International Journal of Learning and Intellectual Capital, Vol.8, No.1, pp.5-15.

8. Burja C. (2012), Human capital's impact on the performance of Romanian knowledgebased companies. Annals of University of Oradea, Economic Series, Vol.21, Issue2, pp.337-342.

9. Costa R., Dorrego P.F., Jardon C.F. (2015), An empirical analysis of the influence of human capital on product innovation performance. International Journal of Engineering and Industrial Management, Vol.3, pp.127-149.

10. Lafuente E., Rabetino R. (2011), Human capital and growth in Romanian small firms. Journal of Small Business and Enterprise Development, Vol 18, Issue 1, pp.74-96.

11. Lefter V., Prejmerean M., Vasilache S. (2008), The dimensions of organizational intelligence-a human capital perspective. Theoretical and Applied Economics, pp.39-52.

72 DE GRUYTER OPEN
Studia Universitatis "Vasile Goldis" Arad. Economics Series Vol 26 Issue 3/2016 ISSN: 1584-2339; (online) ISSN: $2285-3065$

Web: publicatii.uvvg.ro/index.php/studiaeconomia.Pages $62-73$ 
Neagu O., Lazăr V., Mircea T., Macarie S. (2016)

Human capital quality and development: an employers' and employees' comparative insight

12. Marimuthu M., Arokiasamy L., Ismail M. (2009), Human capital development and its impact on firm performance: evidence from develomental economics. The Journal of International Social Research, Vol.2 (8), pp.266-272.

13. Massingham P.R., Tam L. (2015), The relationship between human capital, value creation and employee reward. Journal of intellectual capital, Vol.16, Issue 2, pp.390-418.

14. Neagu O. (2012), Measuring the effects of the human capital on growth in the case of Romania. Annals of Dunarea de Jos University, Galati, Fascicle I Economics and Applied Informatics, No. 1/2012, pp.83-92,

15. OECD (1998), Human Capital Investment: An International Comparison. Paris: OECD Publishing.

16. OECD (2001), The Well-being of Nations: The Role of Human and Social Capital. OECD Publishing, Paris.

17. OECD, Eurostat, WHO (2011), A System of Health Accounts 2011. OECD Publishing.

18. Pribac L., Anghelina A., Blaga R.L. (2016), Return on investment in education.Case study on education in Romania. Studia Universitatis "Vasile Goldiş", Economic Series, Vol.26 Issue 1, pp. 26-39.

19. Rastogi P.N. (2002), Sustaining enterprise competitiveness -is human capital the answer. Human System Management, 19(3), pp.193-203.

20. Schultz T.W. (1961), Investment in human capital. American Economic Review, 51 (1) pp.1-17.

21. Schultz T.W. (1993), The economic importance of human capital in modernization. Education Economics, 1(1), pp.13-19.

22. Wang M., Lu X., Zhao Y. (2012), The quality of enterprise human capital: empirical evidence based on enterprise survey in China. Public Personal Management, Vol.42, No4, pp.735-747.

23. Weatherly L.A. (2003), Human Capital - The Elusive Asset; Measuring and managing Human Capital. Alexandria: Society for Human Resource Management.

24. World Bank (2006), Where is the Wealth of Nations? Measuring Capital for the 21st Century. The World Bank. 